\title{
Analyze The Effects of Helical Baffles Angles Variation On Shell Side Heat Transfer Coefficient And Pressure Drop of Shell And Tube Heat Exchanger
}

\author{
Linta Atina Rahmah ${ }^{1}$, Devy Setiorini Sa'adiyah ${ }^{2}$, Sulistijono ${ }^{3}$ \\ ${ }^{1}$ Mechanical Engineering Course, Industry and Process Technology Department, Technology Institute of \\ Kalimantan, Balikpapan. Email: 03131005@itk.ac.id \\ ${ }^{2}$ Mechanical Engineering Course, Industry and Process Technology Department, Technology Institute of \\ Kalimantan, Balikpapan.. Email: devysetiorini@itk.ac.id \\ ${ }^{3}$ Material and Metallurgical Engineering Course, Earth and Environment Department, Technology Institute of \\ Kalimantan, Balikpapan. Email: sulistijono@mat-eng.its.ac.id
}

\begin{abstract}
E-201-11 is one of the components of heat exchanger which serves to increase the temperature of distillated crude oil before it going into the furnace. The use of segmental baffles on the heat exchanger causes dead zone. The fouling phenomenon that arises from the deposition of the compound content in the service fluid in dead zone can result in leakage of the shell and tube. It affects the performance of heat exchanger and production efficiency. The use of discontinuous helical baffle on the shell side minimizes fouling. Research on the variation of helical baffle angle by using Bell-Delaware method resulted in performance value of heat transfer coefficient and pressure drop on the shell side. Fluid flow behavior on the shell side with helical baffle was analyzed by Computational Fluid Dynamics (CFD). The fluid flow velocity is a factor that affects the value of heat transfer coefficient and pressure drop. Heat exchanger with an angle of $10^{\circ}$ have fluid flow velocity of $0,893 \mathrm{~m} / \mathrm{s}$ resulting in the highest heat transfer coefficient and pressure drop value compared to angles of $15^{\circ}$ and $20^{\circ}$ with values of $585.725 \mathrm{~W} / \mathrm{m}^{2} \mathrm{~K}$ and $13642.395 \mathrm{~Pa}$. The heat exchanger with helical baffle at $10^{\circ}$ helix angle presents the best performance among the others variant helical baffles
\end{abstract}

Keywords: Shell and tube heat exchanger, helical baffle, heat transfer coefficient, pressure drop, shell.

\begin{abstract}
Abstrak
E-201-11 merupakan salah satu komponen penukar panas yang berfungsi untuk meningkatkan temperatur hasil dari distilasi crude oil sebelum masuk ke dapur pemanas. Penggunaan segmental baffle pada heat exchanger menimbulkan dead zone. Fenomena fouling yang ditimbulkan dari pengendapan kandungan senyawa dalam fluida service pada daerah dead zone dapat mengakibatkan kebocoran shell dan tube. Hal tersebut berpengaruh terhadap performa heat exchanger dan efisiensi produksi. Penerapan helical baffle jenis diskontinupada sisi shell dapat mencegah terjadinya fouling. Penelitian terhadap variasi sudut helical baffle dengan menggunakan metode Bell-Delaware menghasilkan nilai performa koefisien perpindahan panas dan pressure drop pada sisi shell. Karakteristik aliran fluida pada sisi shell dengan jenis helical baffle dianalisis dengan Computational Fluid Dynamics(CFD). Kecepatan aliran fluida merupakan faktor yang mempengaruhi nilai koefisien perpindahan panas dan pressure drop. Heat exchanger dengan sudut $10^{\circ}$ memiliki kecepatan aliran fluida 0,893 $\mathrm{m} / \mathrm{s}$ sehingga menghasilkan nilai koefisien perpindahan panas dan pressure drop terbesar dibandingkan dengan sudut $15^{\circ}$ dan $20^{\circ}$ dengan nilai $585,725 \mathrm{~W} / \mathrm{m}^{2} \mathrm{~K}$ dan $13642,395 \mathrm{~Pa}$. Helical baffle dengan sudut $10^{\circ}$ menghasilkan performa optimal pada heat exchanger.
\end{abstract}

Kata kunci: Shell and tube heat exchanger, helical baffle, koefisien perpindahan panas, pressure drop, shell.

\section{Introduction}

Heat exchanger is one of the important components that used in the process in the industry. In the chemical industry, power generation and oil processing, 30-40\% of heat exchangers used are shell and tube heat exchangers (Wang, 2010). Baffle is one of the main components of the shell and tube heat exchanger. Baffle serves as a tube bundle support and directs flow in the shell to obtain a large heat transfer coefficient value. The use of segmental baffle type most widely and commonly used than the other baffle types. The use of segmental baffles has some limitations, one of them is produces a large pressure drop. The pressure drop affects the amount of pressure that the pump must generate. Another limitation is the occurrence of the dead zone. It resulting in fouling resistance that can affect heat transfer, and increase the risk of damage caused by the vibration generated fluid flow (Zhang et al., 
2013). Based on the research, the formulation of baffle helical type design method and the replacement of segmental baffle type into helical baffle was able to reduce the pressure drop with the average of the same overall heat transfer (Zhang et al., 2010). The arrangement of helical baffles in the heat exchanger accelerates the fluid flow which causes the pressure drop to be smaller and produces greater heat transfer on the shell side with the same pressure drop (Gao et al., 2015). The helical baffle configuration consists of two types, there are discontinuous and continuous arrangement. The discontinuous fabrication process is easier than the continuous type, so the discontinuous helical baffle is more widely used (Salahuddin et al., 2015). Helical baffles of the discontinuous type have several forms, including quadrant and trisection form. Quadrant helical baffles are applied to the shell and tube heat exchanger with the type of square tube layout while for trisection applied to triangular tube layout (Dong et al., 2015). Figure 1 shows a discontinuous helical baffle design with a quadrant end to end baffle type in a cycle of helical patterns on the shell side.

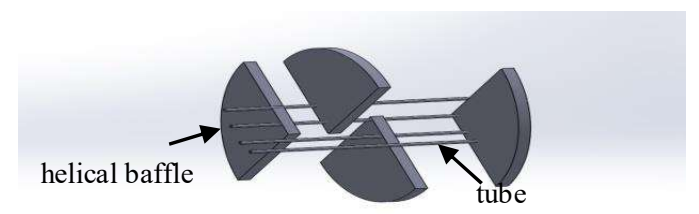

Figure 1. The Arrangement of Discontinuous Quadrant end to end Helical Baffle

The distance of each discontinuous baffle has two types of variation, namely the arrangement of overlap and the end to end baffle. The overlap baffle arrangement has optimal heat transfer performance in smaller overlap proportions (Gao et al., 2013). The heat transfer and the friction on the overlap are larger than the end to end baffles but the ratio between the heat transfer and the friction on the overlap baffle is smaller than the end to end baffle (Dong et al, 2015). Based on these, shell and tube heat exchanger E-201-11 at CDU V PERTAMINA (Persero) RU V Balikpapan is researched by modifying segmental design into helical and analyzing the effect of baffle angle variation on heat transfer coefficient and pressure drop on the shell side It also to analyze flow characteristics based on Computational Fluid Dynamics (CFD) analysis. Variations of helical angles are $10^{\circ}, 15^{\circ}$, and $20^{\circ}$.

\section{Numerical Method}

In order to calculate the performance of shell side heat exchanger using Bell-Delaware method which have been adapted for helical baffle arrangement by Stehlik et al. Helical pitch is the length in a helical cycle that is determined as follows (Tao et al., 2007):

$$
B=\pi D_{i} \tan \beta
$$

Which is:

$\mathrm{D}_{\mathrm{i}}$ is shell diameter

$\beta$ is helical baffle angles

The number of helical baffle is calculated by (Azar et Al., 2016):

$$
\mathrm{N}_{\mathrm{b}}=\frac{4\left(\mathrm{~L}-\mathrm{L}_{\mathrm{b}, \mathrm{i}}-\mathrm{L}_{\mathrm{b}, 0}\right)}{3}+1
$$

Which is:

$\mathrm{L}$ is effective length tube

$\mathrm{L}_{\mathrm{b}, \mathrm{L}}$ is inlet length tube

$\mathrm{L}_{\mathrm{b}_{z}, \mathrm{o}}$ is outlet length tube

The heat transfer coefficient of helical baffles is given as (Azar et al., 2016):

$$
\mathrm{h}_{\mathrm{s}}=\mathrm{h}_{\mathrm{id}} \mathrm{J}_{\mathrm{b}} \mathrm{J}_{\mathrm{s}} \mathrm{J}_{\mathrm{T}} \mathrm{J}_{\mathrm{sh}} \mathrm{J}_{\mathrm{fumh}}
$$


Which is:

$\mathrm{h}_{\mathrm{id}}$ is heat transfer coefficient of ideal tube bank

$J_{b}$ is correction factor of the bundle bypass

$J_{z}$ is correction factor of inlet and outlet

$\mathrm{J}_{\mathbf{r}}$ is correction factor of the temperature gradient

$J_{\mathrm{ch}}$ is correction factor of cross flow characteristic

$J_{\text {turk }}$ is correction factor of the turbulence enhancement

The heat transfer coefficient of ideal tube bank is determined by:

$$
\mathrm{h}_{\mathrm{id}}=\frac{\mathrm{Nu}_{\mathrm{in}} \mathrm{k}_{\mathrm{i}}}{\mathrm{I}}
$$

Which is:

$\mathrm{Nu}_{5}$ is Nusselt number

$\mathrm{k}_{5}$ is thermal conductivity

1 is length characteristic

Pressure drop of the discontinuous helical baffles is calculated by the crossflow area and area along the baffle arrangement which the equation is given as (Azar dkk, 2016):

$$
\Delta \mathrm{P}_{\mathrm{s}}=\Delta \mathrm{P}_{\mathrm{si}}+\Delta \mathrm{P}_{\mathrm{i}-\mathrm{s}}
$$

Which is:

$\Delta \mathrm{P}_{\mathrm{cr}}$ is pressure drop of cross flow area

$\Delta \mathrm{P}_{\mathrm{cr}}$ is pressure drop in along of the baffle arrangement

The shell side pressure drop also written as:

$$
\Delta P_{s}=\Delta P_{b, j d}\left(\frac{1 \text { to }}{B}+2 Z_{s}\right) Z_{b} Z_{c h} Z_{\text {tub }}
$$

Which is:

$\Delta \mathrm{P}_{\mathrm{b}, \mathrm{id}}$ is pressure drop of ideal tube bank in a helical cycle.

$L_{\text {to }}$ is baffle length along tube bundle

$\mathrm{Z}_{\mathrm{s}}$ is correction factor of the baffle space in inlet and outlet shell

$\mathrm{Z}_{\mathrm{b}}$ is correction factor of the bypass fluid in tube bundle

$\mathrm{Z}_{\mathrm{ch}}$ is correction factor of the cross flow characteristic

$\mathrm{Z}_{\text {turb }}$ is correction factor of turbulence enhancement

The ideal tube bank pressure drop is calculated by:

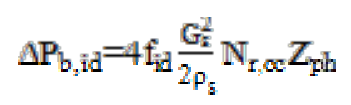

Which is:

$\mathrm{f}_{\mathrm{i}}$ is fanning friction factor

$\mathrm{G}_{\mathrm{s}}$ is fluid velocity mass

$\mathrm{N}_{\mathrm{r}, \mathrm{cc}}$ is number of tube row through the cross flow

$\mathrm{Z}_{\mathrm{ph}}$ is correction factor of thermal physic

\section{Computational Fluid Dynamics (CFD) Analysis Preprocessing}

The preprocessing step is begin by the made of geometry model of quadrant end to end discontinuous helical baffles in shell side of shell and tube heat exchanger for $10^{\circ}, 15^{\circ}$ dan $20^{\circ}$ angles. The angle 
variation is determined by the researches and the operation state of E-201-11 heat exchanger. In the next step is determined of the physic parameter from the boundary condition, which are:

Table 1. Boundary condition of heat exchanger geometry

\begin{tabular}{cc}
\hline Specification & Boundary Condition \\
\hline Inlet & Velocity inlet \\
Shell & Wall adiabatic \\
Baffle & Wall adiabatic \\
Outlet & Outflow \\
\hline
\end{tabular}

The last step of it is discretization or meshing process with volume meshing. The meshing process is a process divided the object into the smaller pieces. It is the important process of the CFD analysis.

\section{Processing}

The steps in the processing process are determination of solving method, fluid operation state, characteristic convergence, and iteration. The calculation based on equation have been done in this step. Simulation parameter of CFD for heat exchanger is given in Table 2 as:

Table 2. CFD simulation geometry parameter of heat exchanger

\begin{tabular}{|c|c|}
\hline Specification & Parameter \\
\hline Viscous model & $\begin{array}{l}\text { Energy : off } \\
\text { K-epsilon standart }\end{array}$ \\
\hline Model geometri & 3 Dimensi \\
\hline Jenis Aliran & Steady \\
\hline \multirow[t]{6}{*}{ Material property } & Fluid \\
\hline & Name: desalted crude \\
\hline & Density $: 684 \mathrm{~kg} / \mathrm{m}^{3}$ \\
\hline & Solid \\
\hline & Name: carbon steel \\
\hline & Density $: 8030 \mathrm{~kg} / \mathrm{m}^{3}$ \\
\hline Velocity magnitude & $0,87 \mathrm{~m} / \mathrm{s}$ \\
\hline Gauge pressure & 0 \\
\hline \multirow[t]{8}{*}{ Method } & Scheme: SIMPLE \\
\hline & Spatial Discretization \\
\hline & Gradient : Least Squares Cell Based \\
\hline & Pressure : Second Order \\
\hline & Momentum : Second Order Upwind \\
\hline & $\begin{array}{l}\text { Turbulent Kinetic Energy : First Order } \\
\text { Upwind }\end{array}$ \\
\hline & Turbulent Dissipation Rate : First Order \\
\hline & Upwind \\
\hline Solution & Initialization Method: Standard Initialization \\
\hline
\end{tabular}

\section{Postprocessing}

The result of the iteration calculation is presented by visualization of distribution and direction of velocity vector in shell side of shell and tube heat exchanger for different helical baffle angels.

\section{Result and Discussion}

\section{Calculation Result}

Based on Bell-Delaware method that the calculation result is given in Table 3 as: 
Table 3. Calculation result

\begin{tabular}{cccc}
\hline Angle $\left({ }^{\circ}\right)$ & $\begin{array}{c}\text { Heat Transfer } \\
\text { Coefficient }\left(\mathbf{W} / \mathbf{m}^{\mathbf{2}} \mathbf{K}\right)\end{array}$ & Pressure Drop (Pa) & $\begin{array}{c}\text { Heat Transfer } \\
\text { Coefficient } / \text { Pressure } \\
\text { Drop }\left(\mathbf{W} / \mathbf{m}^{\mathbf{2}} \mathbf{K P a}\right)\end{array}$ \\
\hline 10 & 585,725 & 13642,395 & 0,043 \\
15 & 494,225 & 4272,720 & 0,116 \\
20 & 448,085 & 2058,596 & 0,177 \\
\hline
\end{tabular}

\section{Fluid Flow Characteristics}

Figure 2 represents the path line characteristic on the shell side of the helical baffle. The flow patterns are spiral and flow continuously. It promotes fluid mixing in shell side and preventing the fouling.

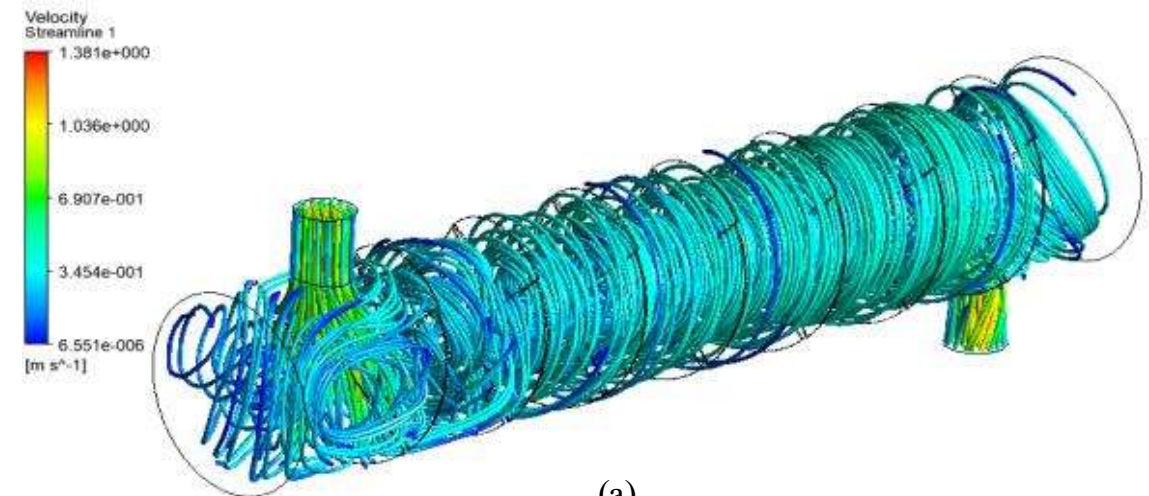

(a)
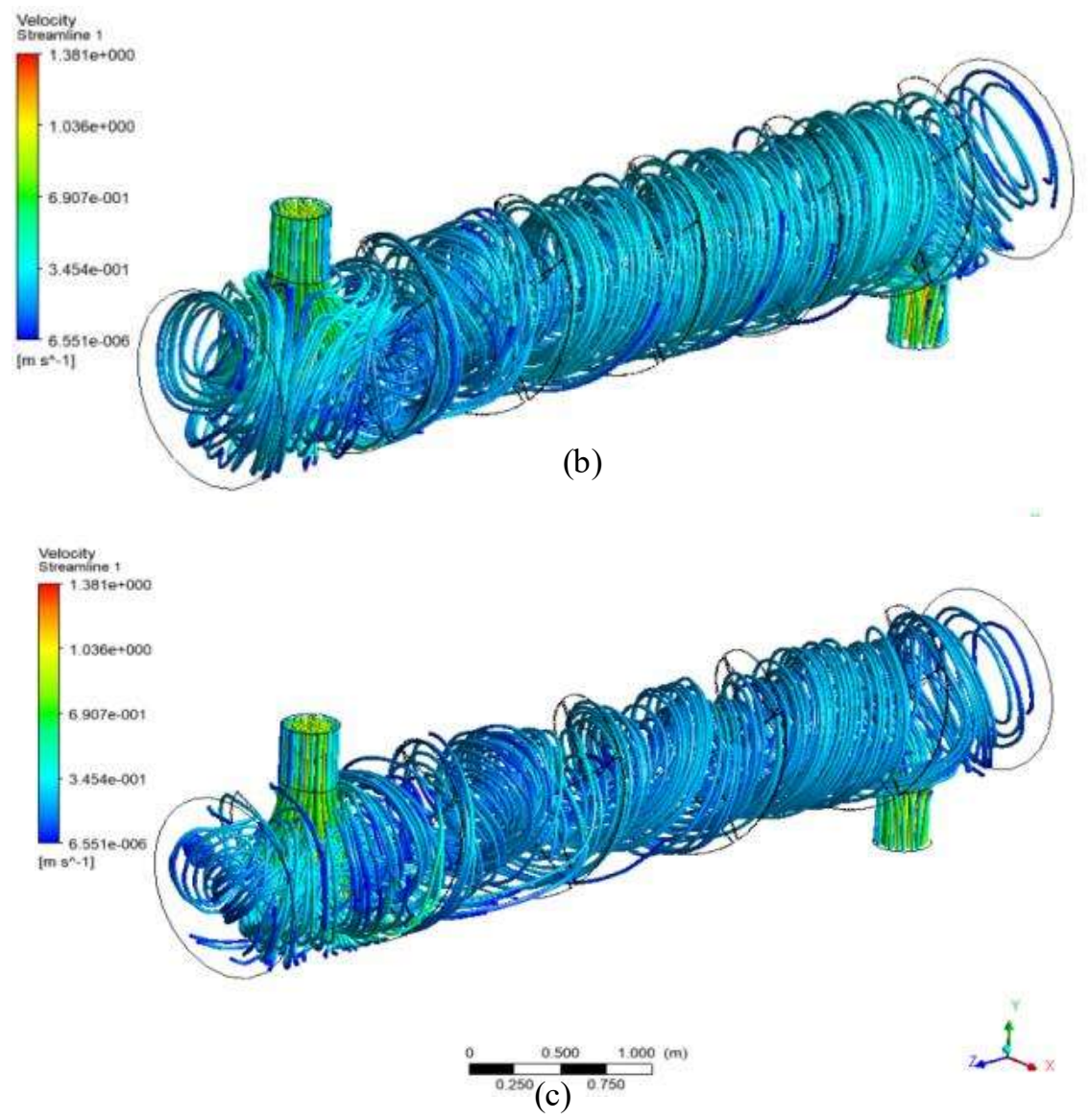

Figure 2. Pathline Flow Patterns in the Shell Side for Different Helical Baffle (a) $10^{\circ}$, (b) $15^{\circ}$, and (c) $20^{\circ}$ 
Figure 2 shows the area that through the shell side the $10^{\circ}$ helical baffle angle is wider than the others. The $20^{\circ}$ is the narrowest area because the fluid flow is not through around to the all part of shell side. Increasing the helical angles affected to grow of boundary layer thickness so that the heat transfer decrease with the increase of the helical baffle angle.

Fluid velocity vector in the shell side with helical baffles is shown in Figure 3. The use of helical baffle is different from the segmental baffle. Whereas, the dead zone does not occur in the fluid flow around the side of baffles so that it has the better fouling resistance than segmental baffle. Helical baffle not only have no dead zone but also have no backflow, so the pressure drop is lower than the segmental baffle. The V-notch in the adjacent baffle is reported by the Figure 3. At the V-notch there is leakage helical fluid flow because the fluid does not through around the shell. It through to the next helical cycle immediately. The $10^{\circ}$ helical baffle is the narrowest $\mathrm{V}$-notch and $20^{\circ}$ is the widest area.

Based on Figure 3 that can be observed the fluid turbulence of helical baffle that represented by the velocity vector. The smaller helical angles, the more randomly turbulence fluid. The turbulence is affected the Reynold number. The more randomly turbulence fluid, the higher Reynold number.

The spiral fluid pattern of helical baffle reduce the friction losses and prevent the tube from vibration. Figure 3 illustrates the centripetal force generate the fluid flow outward at the starting section. The radial pressure difference produce the centrifugal force to get the equilibrium state that causing the inward fluid in the ending section of each cycle.

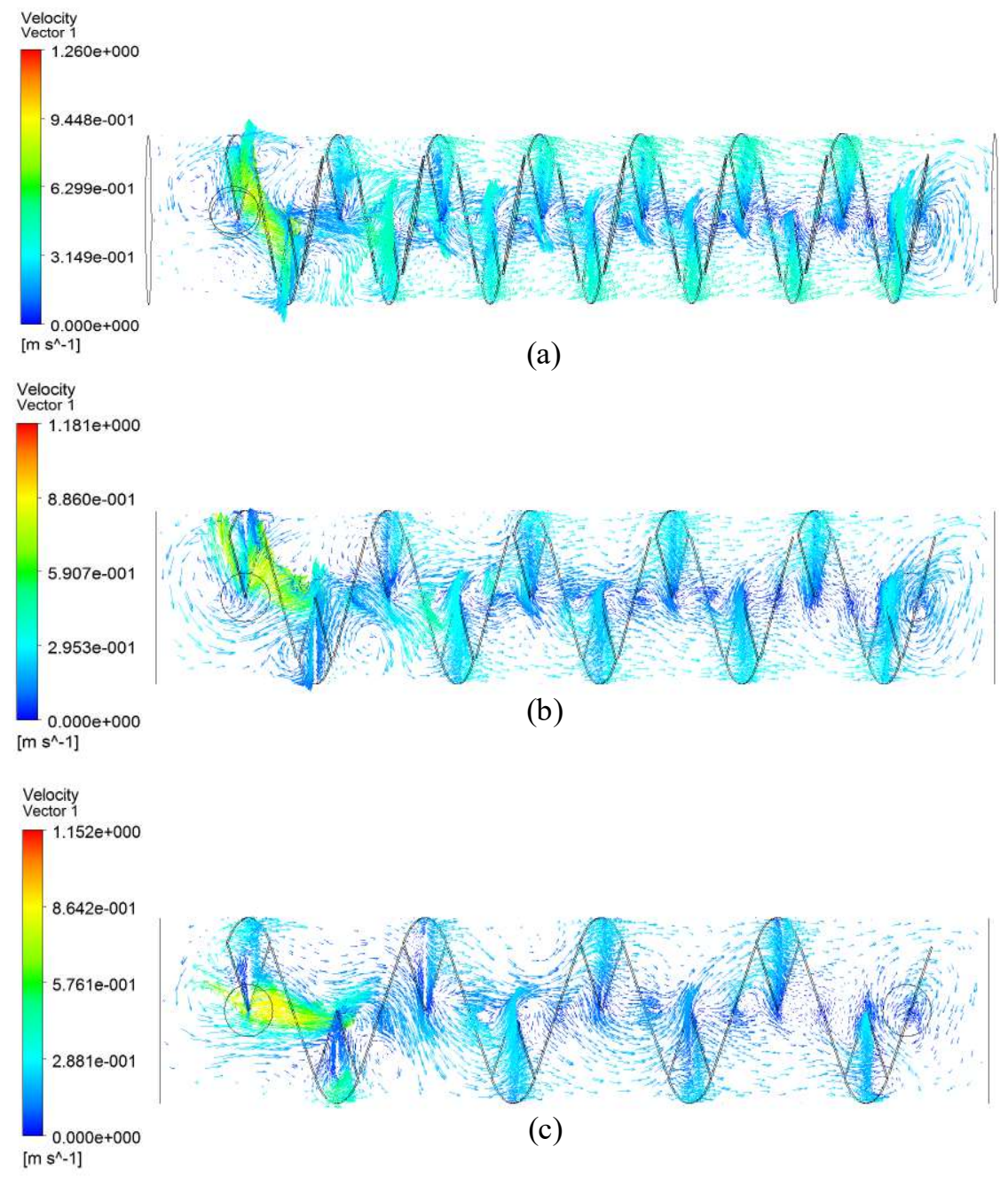

Figure 3. Shell Side Velocity Vector Distribution for Different Helical Angles (a) $10^{\circ}$, (b) $15^{\circ}$, and (c) $20^{\circ}$ 


\section{Shell Side Heat Transfer Coefficient}

The heat transfer coefficient for different helical baffle angles that reported in Figure 4 shows the increasing helical angles leading to decrease the heat transfer coefficient. The highest heat transfer coefficient occurs in $10^{\circ}$ with $585,725 \mathrm{~W} / \mathrm{m}^{2} \mathrm{~K}$ value and $448,085 \mathrm{~W} / \mathrm{m}^{2} \mathrm{~K}$ is the lowest value that occurs at the $20^{\circ}$ helical baffle.

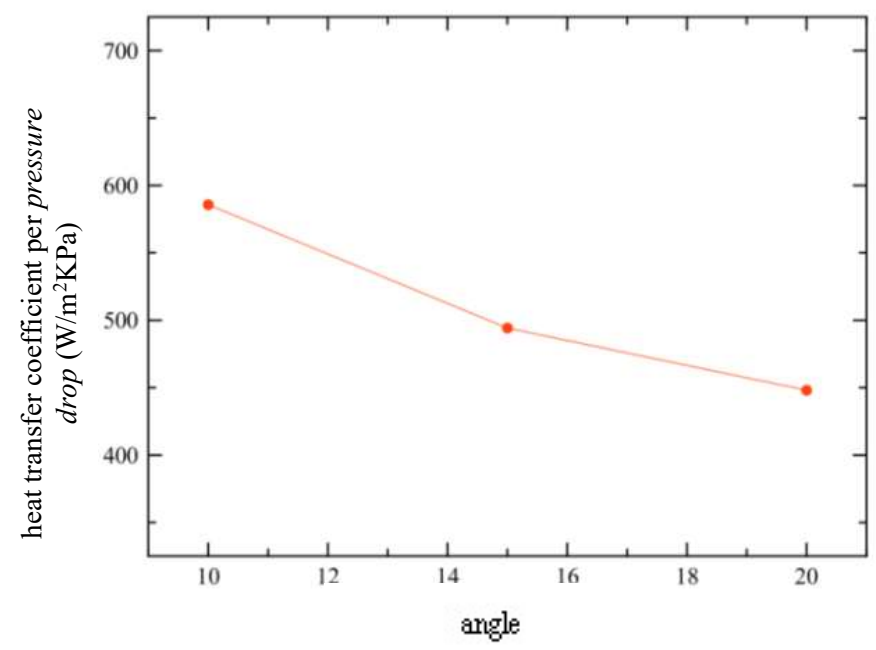

Figure 4. Heat Transfer Coefficient for Different Helical Baffle Angles in Shell Side Heat Exchanger

Based on the 1 equation that helical pitch is reduced when the angle is getting smaller. It caused the crossflow area getting narrower so that the fluid velocity is increasing. The increasing value not only occurs for Reynold number but also occur for fluid velocity. The increasing Reynold number also followed by the Nusselt number. The higher Nusselt number will create the higher heat transfer coefficient too. The form of V-notch also influences the heat transfer coefficient. The leakage of the fluid flow resulted the lower fluid velocity. Due to the lower velocity will affected to the decrease of the heat transfer coefficient.

\section{Shell Side Pressure Drop}

Figure 5 reports the influence of different helical baffle angles for pressure drop in shell side. The $10^{\circ}$ have the highest value, that is $2058,596 \mathrm{~Pa}$ and $20^{\circ}$ is the lowest shell side pressure drop with $2058,596 \mathrm{~Pa}$ value. Increasing helical baffle angles is followed by the decreasing of pressure drop.

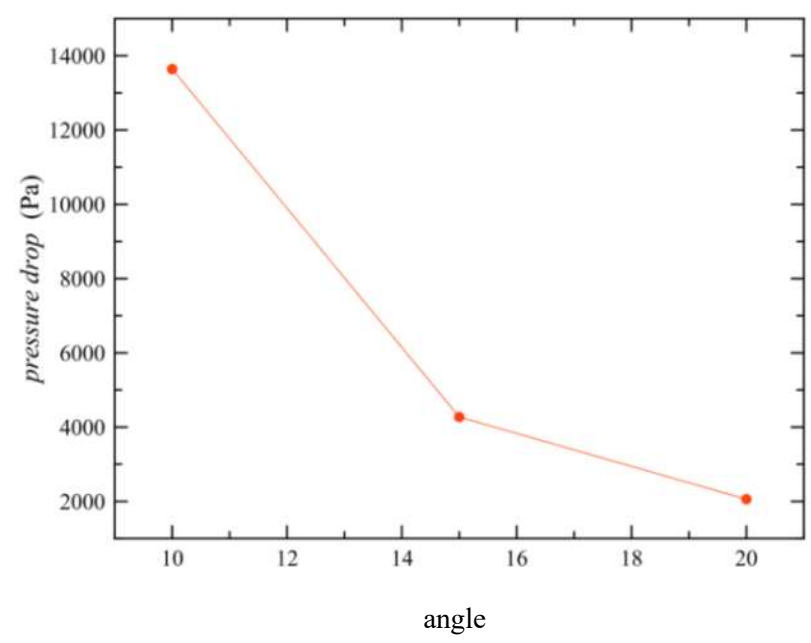

Figure 5: Shell Side Pressure Drop for Different Helical Baffle Angles in Shell Side Heat Exchanger 
Fluid mass velocity is one of the factors of the pressure drop value. It is the influence of the helical pitch that affected by the helical baffle angles. The larger value of helical pitch, the wider area of fluid cross flow. The constriction of cross flow area tends to the increasing of fluid mass velocity. The increasing of fluid mass velocity is followed by the raising of pressure drop. The other factors are fanning friction factor that affected ideal tube bank pressure drop by the Reynold number. The correction factor value will be increase with the raising of Reynold number. Reynold number is affected by the fluid velocity that can be observed in turbulence simulation. V-notch is also the factor to determine the pressure drop in shell side. The significant trend line is caused by the fluid mass velocity for $10^{\circ}$ to $15^{\circ}$ helical baffle angles that have the higher ratio than the other helical baffle angles.

\section{Shell Side Performance Analysis}

$\mathrm{V}$-notch is created in the adjacent baffle that $10^{\circ}$ helical baffle angle has the smallest area. The shortest helical pitch of it generates the nozzle in the area of $\mathrm{V}$-notch. The decreasing nozzle area will impact to increase the fluid velocity. The fluid velocity is the main factor for determining the heat transfer coefficient and pressure drop. Whereas, the increasing of fluid velocity is more effective for increasing the heat transfer coefficient and pressure drop.

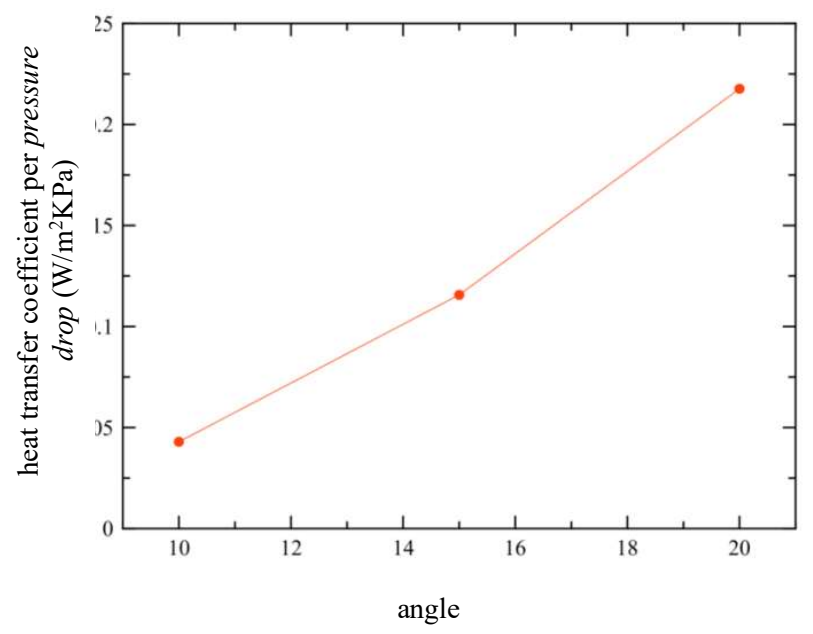

Figure 6. Heat Transfer Coefficient per Pressure Drop for Different Helical Baffle Angles in Shell

Side

The $10^{\circ}$ helical baffle angle has the highest value of heat transfer coefficient and pressure drop. And the $20^{\circ}$ helical baffle angle has the lowest value of it. It makes clear to have the comparison of heat transfer coefficient and pressure drop that was shown in Figure 6. It is understood that the increasing baffle helical angles are more effective to raise the ratio of heat transfer coefficient and pressure drop in shell side. The effort to increase the performance of it is gets the high value of fluid velocity that can be reached by the modification of helical baffle angles and arrangement.

\section{Conclusion}

Based on the research, the same flowrate in helical baffle arrangement affected the heat transfer coefficient and pressure drop in shell side. The summary are:

1. Shell side heat transfer coefficient have the highest value in $10^{\circ}$ helical baffle angle for $585.725 \mathrm{~W} / \mathrm{m}^{2} \mathrm{~K}$ and the lowest value in the $20^{\circ}$ helical baffle angle for $448.085 \mathrm{~W} / \mathrm{m}^{2} \mathrm{~K}$.

2. Shell side pressure drop has the highest value in $10^{\circ}$ helical baffle angle for $13642.395 \mathrm{~Pa}$ and the lowest value in the $20^{\circ}$ helical baffle angle for $2058.596 \mathrm{~Pa}$.

3. As the helical baffle angles are increased, the shell side heat transfer coefficient and pressure drop increase for all the helical baffle angles.

4. The fluid velocity needs to be raised to get the more effective heat transfer coefficient in shell side. 
5. The raising fluid velocity can be reached by the use of $10^{\circ}$ helical baffle angle.

\section{References}

Azar, R. T., Khalilarya, S., Jafarmadar, S., dan Ranjbar, F. (2016), "Modelling for Shell-Side Heat Transfer Coefficient and Pressure Drop of Helical Baffle Heat Exchangers", Journal of Heat Transfer Engineering, Vol. 38, No. 2, Page 265-277.

Dong, C., Ya, P.C., dan Jia, F.W. (2015), "Flow and Heat Transfer Performances of Helical Baffle Heat Exchangers With Different Baffle Configurations", Journal of Applied Thermal Engineering, Vol. 80, Page 328-338.

Gao, B., Bi, Q., dan Nie, Z. (2013), “ Effects of Baffle Overlap Proportion on Shell-Side Performance of Shell and Tube Heat Exchanger With Helical Baffles", ASME 2013 Power Conference, Power Divison, Boston.

Gao, B., Bi, Q., Nie, Z., dan Wu, J. (2015), "Experimental Study of Effects of Baffle Helix Angle on Shell Side Performance of Shell And Tube Heat Exchangers With Discontinuous Helical Baffles", Journal of Experimental Thermal And Fluid Science, Vol. 68, Page 48-57.

Husainiy, M.Q.A., dan Nugroho, G. (2014), Investigasi Karakteristik Perpindahan Panas Pada Desain Helical Baffle Penukar Panas Shell and Tube Berbasis Computational Fluid Dynamics (CFD, Tugas Akhir, Institut Teknologi Sepuluh Nopember Surabaya, Surabaya.

Salahuddin, U., Bilal, M., dan Ejaz, H. (2015), “ A Review of The Advancements Made in Helical Baffles Used in Shell and Tube Heat Exchanger", Journal of International Communications in Heat and Mass Transfer, Vol. 67, Page 104-108.

Tao, Wenquan, Li, Bin, dan He, Yaling. (2007), "Determination of Helical Lead Distance of Shell-and-Tube Heat Exchanger With Helical Baffles", Journal of Chemical Industry and Engineering (China), Vol. 58, No 3, Page 587-590.

Wang, Q., Chen, G., Chen, Q., dan Zeng, M. (2010), "Review of Improvement on Shell and Tube Heat Exchangers With Helical Baffles", Journal of Heat Transfer Engineering, Vol. 31, No. 10, Page 836-853.

Zhang, J. F., Guo, S. L., Li, Z. Z., Wang, J. P., He, Y. L. (2013), "Experimental Performance Comparison of Shell and Tube Oil Coolers With Overlapped Helical Baffles and Segmental Baffles", Journal of Thermal Engineering, Vol. 58, No. 1-2, Page 336-343.

Zhang, J. F., He, Y. L., dan Tao, W.Q. (2010), "A Design and Rating Method for Shell and Tube Heat Exchangers With Helical Baffles", Journal of Heat Trasnfer, Vol. 132, Page 1-8. 